\begin{tabular}{|l|l|l|l|l|}
\hline ACTA CARSOLOGICA & $32 / 2$ & 25 & $299-306$ & LJUBLJANA 2003 \\
\hline
\end{tabular}

COBISS: 1.01

\title{
HALLERSTEIN AND CHINESE KARST
}

\section{HALLERSTEIN IN KITAJSKI KRAS}

STANISLAV JUZNIČ ${ }^{1}$

${ }^{1}$ Fara 2, 1336 Vas, Slovenia. E-mail: juznic@hotmail.com

Prejeto / received: 2. 5. 2003 


\section{Abstract}

UDC: $551.44: 528.94(510)$

\section{Stanislav Ju]nič: Hallerstein and Chinese Karst}

The life and work of the Carniolan scientist Auguštin Hallerstein was described. Hallerstein's maps of the Chinese karst areas were discussed. The data about his travels through the karst regions were presented. Key words: Hallerstein, Jesuits, Carniola, China, karst, maps.

Izvleček

UDK:551.44:528.94(510)

\section{Stanislav Ju]nič: Hallerstein in kitajski kras}

Opisali smo delo kranjskega znanstvenika Avguština Hallersteina. Obravnavali smo Hallersteinove zemljevide kitajskih kraških območij. Zbrali smo podatke o njegovih potovanjih po kitajskem krasu.

Ključne besede: Hallerstein, jezuiti, Kranjska, Kitajska, kras, zemljevidi. 


\section{INTRODUCTION}

On August 28, 2003, three centuries passed from the birth of Avguštin Hallerstein (17031774) in Ljubljana. He finished his lower and upper studies at the Jesuit college Ljubljana and competed his mathematical learning in Vienna and in Portugal. Hallerstein's abilities in geometry were developed in collaboration with the Viennese rector Johann Baptist Thullner, (1668-1747), former professor of mathematics in Ljubljana. Thullner's Geometry of 1711 was one of the best Jesuit works ever published.

Hallerstein was among the first Europeans to draw the maps of the Chinese karst regions. On January 21, 2003, the post of Slovenia issued the stamp to honor the $300^{\text {th }}$ anniversary of Hallerstein's birth. On August 28, 2003, the memorial tablet was unveiled at Hallerstein's family castle in Mengeš.

\section{NORTH OF THE GREAT WALL}

The mapmaking was the Jesuit fashion of Hallerstein's time. Mattheo Ricci (1552-1610) draw the first map of China for Europeans. Xu Xiake (1587-1641) posthumously published the very first systematic research of the Chinese Karst in 1642 (Ravbar 2003, 249).

Martin Martini (1614-1661) published the collection of the China maps in 1655. He described the famous iron chain bridge An-Lan over the karst river in the province of Guizhou. In his time, the province was called Kouei-tcheou and Koey-tscheou (Hallerstein 1780, 292, 378).

Athanasius Kircher (1601-1680) republished Martini's description and other letters of the Chinese missionaries. In the fourth part of his book Kircher described the Chinese mountains, waters, vegetables, mammals, birds, fishes, snakes, stones, and minerals. Among Kircher's collaborators was the Chinese missionary Johann Gruber (1623-1680) who traveled for three years before he returned to Rome in 1664 .

Between 1689 and 1698, the astronomer and geographer Jean François Gerbillon (1654-1717) accompanied the Chinese emperor to Tatary for eight times. In 1692, he finished the map of the Great Tatary in the northern China. On emperor's order, Joachim Bouvet (1656-1730) and Jean Baptiste Régis mapped the Great Wall. In June 1708, the Jesuits Pierre Jartoux (1669-1720), Ehrenwert Xaver Fridelli (1673-1739), Cardoso, de Tartre, Joseph Marie Anne de Moyriac de Mailla (1669-1748), Roman Hinderer, Régis, and the augustinian Bonjour began to draw the maps of the lands near the border of Korea. For seven years, Fridelli traveled through the empire and issued the map of the whole empire with Mongolia and Manchuria up to the Russian border. The Jesuit Jean Baptiste Du Halde (1674-1743) published the Jesuit maps of China compiled by the best geographer of his time Jean Baptiste Bourguignon d'Anville (1687-1782). D'Anville's redaction became the foundation of the modern maps of China.

Hallerstein continued the mapping of China. In 1738, he draw his first map of Macao. In 1748, Hallerstein and his assistant Felix de Rocha (1713-1781) made the relief map of the province of Mu-lan, today Mulan Paddock on the north side of the easternmost end of the Great Wall in Hebei province. Mulan Weichang was build already in 1681. Nine years later, the emperor defeated the Mongol rebels at a battlefield situated just $15 \mathrm{~km}$ south of Mulan Hunting Ground.

The emperor hunted in Mu-lan every third autumn and urgently needed the accurate map with the description of his chase. At the hinting time, the emperor stayed for three or even five months in those places beyond the Great Wall. The Chengde Mountain Resort of Hebei Province used to 
be the largest summer resort of the Qing Dynasty.

In 1749, Hallerstein and his collaborators carried on the topographic and horographic mapping of Mu-lan, the Tatar land on the northern side of the Great Wall. Besides mapping in modern sense of the world they described the waters, climate, soil, vegetable, and animal world of the area. In between, Rocha performed some astronomical observations. Hallerstein described the uninhabited lands called Har-zin and Oguiot to his brother Baron Vajkard Hallerstein (1706-1780) in Brussels. All area was one continued chain and labyrinth of mountains and valleys, without inhabitants, but full of wild animals, as red deer, wild boars, bears, and tigers. The soldiers guarded all passages of the valleys, and nobody was allowed to pass through them (Pray 1781, 28; Hallerstein 1753, 322).

Rocha and Hallerstein mapped the area one degree wide and one degree long between $41,5^{\circ}$ and $42,5^{\circ}$ of north latitude. On the west, they reached the meridian of Beijing. The Chinese used that meridian as the first one for geography and astronomy. They mapped the north part of the modern province of Hebei with the characteristic karst of the moderate warm, half dry climate. They marked the most suitable hinting areas. The emperor was very pleased. Upon Hallerstein's return the emperor gave him a most gracious reception, and asked many questions concerning the mapped country. At the same time, Hallerstein's Italian friend Giuseppe Castiglione (1687-1766) painted his famous Mulan Hunt.

Hallerstein was the first Carniolan researcher of the Chinese karst. On November 28, 1749, he reported about his observation of Mu-lan karst to his brother Vajkard. On September 18, 1750, he sent the similar, somewhat longer description to Mortimer of the Royal Society. Hallerstein was not able to send them the copies of the maps jet, because the drawing was not accurate enough. Later, his horographical maps were published in Chinese language in Beijing on 120 pages (Bernard 1960, 379). In April 1755, his French friend Antoine Gaubil (1689-1759) sent to the Royal Society several maps of the Chinese lands, probably with Hallerstein's map included (Šmitek 1995, 113).

The northwest corner of Hallerstein's map was on the border of the modern Inner Mongolia (Nei Monggol) near the town Doulun. On the northeast, Hallerstein mapped the area up to the modern province of Liaoning well known for its oil slates that extends up to the Korean border to the east. Hallerstein's map was a square with a side four foot long. Therefore he used the approximate ratio 1 : 90.000. In 1744, Ivan Dizma Florjančič de Grienfeld (1691-after 1757) published the comparable map of Hallerstein's native Carniola in the approximate ratio $1: 111.000$.

Mu-lan in the Hebei Province should not be confused with over ten degrees southern Mulan in the northern part of the County Huangpi near the suburbs of the town Wuhan in Hubei Province, the home of the legendary Chinese girl warrior Mu-lan. Hallerstein's Mu-lan is today preserved as one of the few natural grassland resorts. A part of Mulan Hounting Ground is included in Saihanba National Forest Park with forest covering over three quarters of all area. The park entertains eightyone families of higher plants, eleven families of animals and twenty-seven families of birds.

The modern Hebei Province has three geological parks: the Baishi (White Stone) Mountain in Laiyuan, Liujiang of Qinhuangdao, and Tiansheng (Heaven-made) Bridge of Fuping. On north, the White Stone covers 60 square $\mathrm{km}$ with the only marble rock forest, ten water falls (Shipu), and Juma River. The Liujiang Park is situated $280 \mathrm{~km}$ away from Beijing and covers 186 square $\mathrm{km}$ with the mysterious Xuanyang cave. In that area the Chinese began conducting their first geological survey after Hallerstein's mapping. The Heaven-made Bridge is located about $25 \mathrm{~km}$ west of Fuping and covers an area of 32 square $\mathrm{km}$. The bridge sits above the 112-meter high waterfall, which is formed by metamorphic rock. 


\section{SOUTH OF THE GREAT WALL}

Hallerstein also knew very well the karst region between south of Beijing very well. He traveled through it after his arrival and four more times later on the diplomatic duty.

Table 1: Hallerstein's voyages south of Beijing

\begin{tabular}{lll}
\hline Date & Direction of the travel & Purpose of the trip \\
\hline 1.3.1739-13.6.1739 & Macao-Beijing & Taking over the job at the court \\
25.10.-13.12.1752 & Beijing-Macao & Came to meet the Portuguese delegates \\
20.12.1752-1.5.1753 & Macao-Beijing & Suiting diplomats \\
8. $6 .-6.10 .1753$ & Beijing-Macao & Suiting diplomats \\
9. $10.1753-21.10 .1753$ & Macao-Beijing & Returning to the court \\
\hline
\end{tabular}

In 1752, the emperor ordered the local authorities to help Hallerstein's land transport and river navigation. He had many delays because of the huge suite. On August 15, 1752, the Portuguese ambassador Francisco Xavier Pacheco Lampayo arrived to Macao with the presents for the emperor.

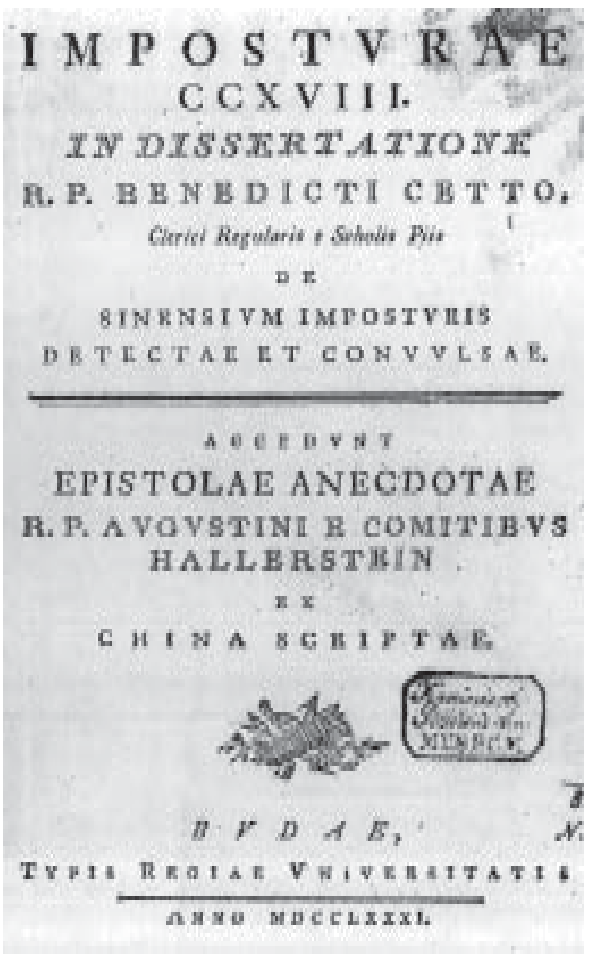

Fig. 1: The front page of Pray's edition of Hallerstein's letters to his brother, containing description of Chinese karst (on pages 28-29).
He replaced the former ambassador Metéllo de Souza, who was took the duty in 1727 . The suite numbered 71 people and they traveled to Beijing for four months. Hallerstein's journeys with smaller groups were certainly much faster. The travelers had troubles with the ground obstacles, high prices, accidents and illness on the numerous meanders they had to travel through. The four successive trips took away all Hallerstein's powers and he had to rest for few months. After his return to Beijing his friend was curious, how he suddenly grew so old. He traversed $5000 \mathrm{~km}$ in a year, and he found the old fashioned Chinese ceremonies especially tiresome.

Most of the time he journeyed through the karst regions. On December 25, 1752, Hallerstein, Tatar mandarin Shu, and diplomats arrived from Macao to Canton. On April 20, 1753 they arrived to Chi-Hoa. Not far north from Macao he traveled through the tropic and subtropic karst in the provinces of Hunan and Hubei, described by $\mathrm{Xu}$ Xiake more than hundred years before. Hallerstein and his companions continued north through the karst of the moderate warm half dry climate in the provinces of Henan and Hebei (Ravbar 2002, 191-192). They returned from the Beijing back to Macao in the company of the mandarin Hay 
(Peyrefitte 1991, 54, 57).

In October, Hallerstein finished his diplomatic mission. On October 21, 1753, he described the travel events to his brother. He mailed the letter from the camp between Im-te-hien and Haochen-sub in Guangdong Province, which he called Quan-tum (Pray 1781, 30-31).

In March 1756, Rocha, José d'Espinha (1722-1788), Ho Kuo Tsung († 1766), and Ming'antu (1712-1764) mapped the recently conquered northwest land of Xinjiang Uygur (Sinkiang). In 1761, Hallerstein and Benoist repaired the maps and gave them as the birthday present to the emperor Qianlong (Semans 1987, 180-181). Hallerstein's maps were later included in the China map in the ratio $1: 1.500 .000$ (Needham \& Ling 1959, 3: 586).

At advanced age, Hallersten was not very willing to travel to the remote lands any more. But he was still very active geographer. He measured the distance between meridians of Beijing and Petersburg and presented to the Europeans the very first accurate census and yearly increment of the Chinese.

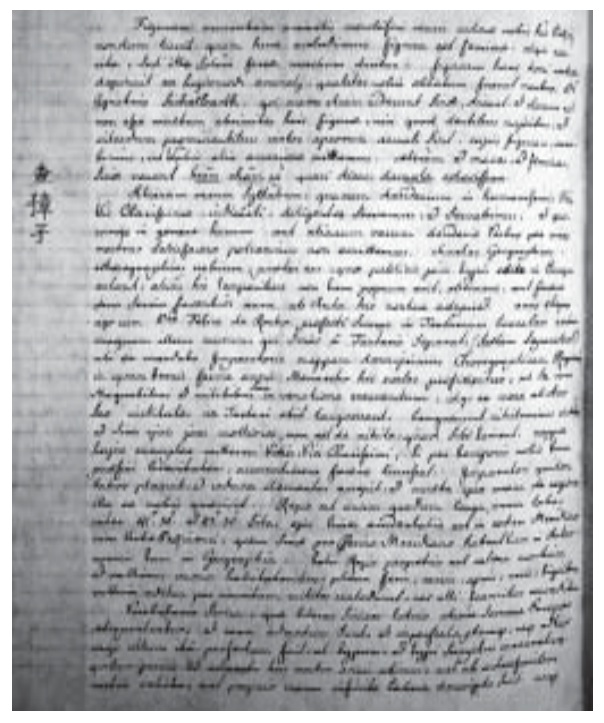

Fig. 2: Hallerstein's letter to the secretary of the Royal Society Cromwell Mortimer († 1752) mailed on September 19, 1750 with the description of his mapping of the karst region in 1749 on page 2 (The Archive of the Royal Society of London).

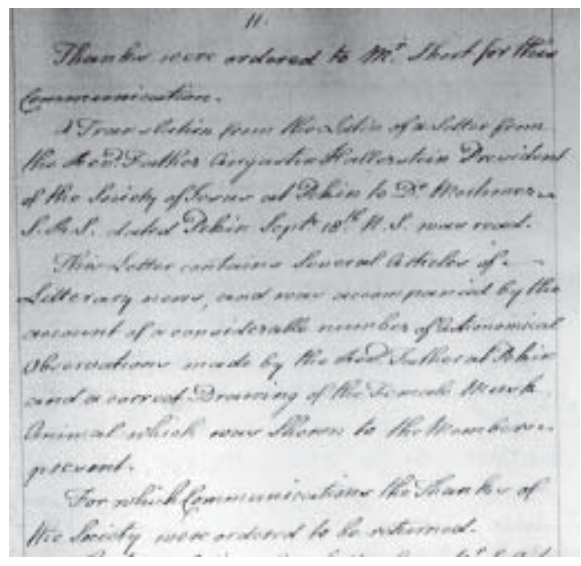

Fig. 3: December 19, 1751 protocol of the Royal Society meeting with notes on the reading Hallerstein's letter about the mapping of the Mu-lan, page 11 (The Archive of the Royal Society of London). 


\section{CONCLUSION}

The Jesuits were very skilled in mapping. Hallerstein probably followed the example of his uncle Inocenc Volbenk Anton Franc Erberg (1694-1766) who mapped Paraguay in 1727. Hallerstein was the most famous among the early visitors of the Chinese karst. He had the opportunity to compare the Far East karst with the domestic one he admired during his September 1735 travel to Trieste, when he saw Carniola for the very last time. He preceded the contemporary Slovene researchers of the Chinese karst.

\section{REFERENCES}

d'Anville, J. B. B., 1737: Nouvel Atlas de la Chine. - Paris.

Bernard, H., 1960: Les Adaptations chinoises d'ouvrages européens: Deuxieme Partie (16891799). - Monumenta Serica. 19: 349-383.

\section{[ 321 ]}

tioni made whth only a micrometer and pendulum

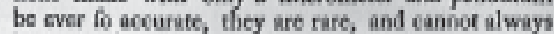
bo made. In the mean time we will pluec the tranit inllrument, and wh it an far an la wh extenda. For a quadrant wh ipply to the court of Libbun, lewile we hive it not in our power to purchide one. And inded, the negut of the wealih of the Jefuits at Pekin is is mere fible.

We hewe not yet had the good fortuse here at Pekin to tha an achirate fighe of the male mish animal i the figure here ineloted is that of the femenle and it is not this, but the male, that is hid to hear the maks. This frgure was drewa in our houls by Father Ignuius gichelbarth, from a dead usimsl, it it wur brought to un. The chingh, who have toun the mals, hy, that is is not moeh unlile this fogre. exepuing thit it hu large teah, and fometimea tuaks like thofe of a boar. on fome other oesaline we will take carb to fend you it figure. In line, the chine enll both the male and fomale baw abow $h_{1}$ which

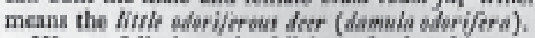

We eirefully keep the fyllabui af ather thisg, of which you delled ob be informed, wist fhall uhe nur endeswours to fatisfy you on the be bealfo and ony other that muy give you plenfure $A$ to geogre phicil mep, ind plan of eithe, it would ba vory

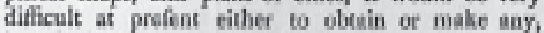
but thofe uleudy publilhed in Europe, until a more

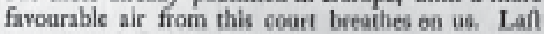
year I and Father Felis de Resehe triqelled ieto Nordi Thitiry, beyond that vait wall, which keparaten (or at leak foparated) the Chinof from the 'Turan ! where by the emperor' order, we drew a 8 it chorgyaphieal

Fig. 4: Hallerstein's report to the Royal Society about the mapping of China regions and especially on his and Rocha's research on the bottom of the page (Hallerstein 1753, 321).

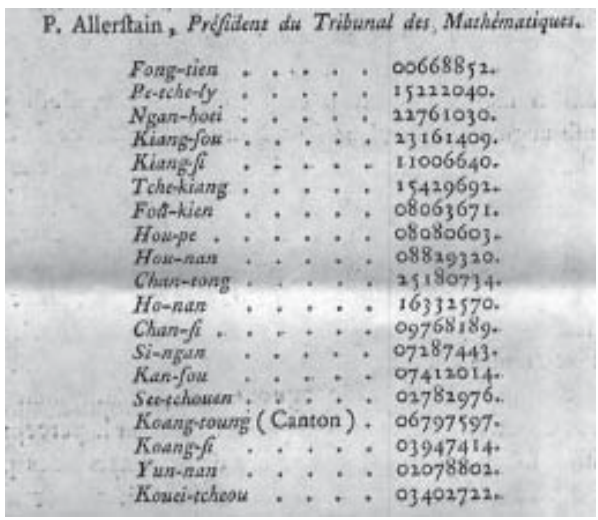

Fig. 5: Hallerstein's numbering, the very first Chinese census published in Europe. French publisher rebaptized our scientist into «Allerstain« (Hallerstein 1780, 292). 
Du Halde, J. B., 1735: Description géographique, historique, chronologique, politique et physique de l'empire de la Chine et de la Tartarie chinoise. - P.G. Lemercier, Paris.

Hallerstein, A., 1753: A Letter from Reverend Father Augustin Hallerstein, of the Society of Jesus, President of the astronomical College at Pekin in China, to Dr. Mortimer, Sec. R.S. Dated Pekin, Sept. 18, N.S. 1750, Translated from the Latin by Tho. Stack, M.D. and F.R.S. - Phil.Trans. 1751-1752. 47: 319-323.

Hallerstein, A., 1780: Dénombrement Des Habitants de la Chine, traduit du chinois, par le seu. P. Allerstain, Président du Tribunal des Mathématiques. - Mémoires, concernant l'histoire, les sciences, les arts, les moeurs, les usages etc. des Chinois, par les missionnaires de Pekin. Paris: Nyon. 6: 292, 374-380.

Kircher, A., 1667: China monumentis, qua Sacris qua profanis, nec non (variis) naturae et artis spectaculis, aliarumque rerum memorabilium argumentis illustrata. - Varesi, Rome.

Martini, M., 1655: Novus Atlas Sinensis. - Joan Bleau, Amsterdam.

Needham, J., Wang Ling, 1959: Science and Civilization in China. Vol. 3. Mathematics, Astronomy, Geography, Cartography, Geology, Seismology and Mineralogy. - Cambridge University Press, Cambridge.

Peyrefitte, A., 1991: Un choc de cultures. La vision Chinois. - Fayam, Paris.

Pray, G., 1781: Imposturae CCXVIII in dissertatione r. p. Benedicti Cetto, Clerici Regularis e Scholis Piis de Sinensium imposturis detectae et convulsae. Accedunt Epistolae anecdotae r. p. Avgustini e comitibus Hallerstein ex China scriptae. - Typis Regiae Universitatis, Budae.

Ravbar, N., 2002: Kitajska kraška terminologija. - Acta carsologica. 31/2: 189-208.

Ravbar, N., 2003: The Earliest Chinese Karstologist Xu Xiake. - Acta carsologica. 32/1: 243-254.

Semans, C.A., 1987: Mapping the Unknown. Jesuit Cartography in China, 1583-1773. - Berkeley, Doktorska Disertacija.

Šmitek, Z., 1995: Srečevanja z drugačnostjo, slovenska izkustva eksotike. - Didakta, Radovljica.

\section{HALLERSTEIN IN KITAJSKI KRAS}

\section{Povzetek}

Hallerstein spada med najpomembnejše kranjske znanstvenike 18. stoletja. Nedvomno je med vsemi dosegel najvišji polo•aj, saj je bil skoraj trideset let predsednik astronomskega urada $\mathrm{v}$ Pekingu. Med njegove dol•nosti je spadalo tudi kartografiranje posameznih provinc ter prevajanje ob obisku portugalskih odposlancev. Tako je slu•beno prepotoval številne kitajske kraške pokrajine. $\mathrm{O}$ njih je poročal v pismih bratu in tajniku kraljeve dru•be v Londonu. Njegova poročila so $\mathrm{v}$ Londonu visoko cenili in objavljali, podobno kot pol stoletja prej poročila o kraških pojavih v Cerkniškem jezeru drugega kranjskega barona Valvasorja.

Hallerstein je zemljevide in opise kitajskih de•el brez večjih zadr•kov s strani kitajskih oblasti pošiljal znanstvenikom v Evropo. Njegovi zemljevidi so bili vključeni v poznejša kitajska dela. 